\title{
Strength Characteristics of Glass Fiber Reinforced Concrete (GFRC) using Calcium Chloride Integral Curing Method
}

\author{
Jaison Joy Memadam, T.V.S Vara Lakshmi
}

\begin{abstract}
Concrete is weak in tension and strong in compression. The inclusions of fibers in concrete significantly improves its compressive as well as tensile strength. The use of different types of fibers have shown positive responses among the researchers. It has long been known that curing concrete during cold weather can result in an inferior product with substandard properties. Curing also takes much longer, adding to job costs and extending the time before the concrete surface can be used. There are many accelerators available in the market, but Calcium Chloride continues to be one of the most preferred one. In this study, Alkali resistant glass fibers $(0 \%, 0.5 \%, 1 \%, 1.5 \%, 2 \%, 2.5 \%$, $3 \%, 3.5 \%$ and $4 \%$ ) were used in the concrete M30 mix. The optimum glass fiber percentage that can be added to the concrete is found by comparing both tensile and compressive strength of the GFRC. Trial mixes of normal M30 concrete by adding different percentages of Calcium Chloride (0\%, 0.5\%, 1\%, 1.5\%, $2 \%$, and $2.5 \%$ ) as curing agent is also prepared. The optimum percentage of calcium chloride that can be added to the concrete is found by comparing the compressive strength of the con-crete. The compressive strength of the GFRC using calcium chloride integral cur- ing is found after 7, 14 and 28 days. The test results are then compared with GFRC using normal curing.
\end{abstract}

Keywords: Calcium chloride, Integral Curing, Accelerator, GFRC, Glass Fiber

\section{INTRODUCTION}

Concrete is the most widely used construction material having several desirable propertieslikehighcompressivestrength,stiffnessanddurabilit yunderusualenviron-

mentalconditions.Itisobtainedbymixingcementingmaterials, waterandaggregates,

andsometimesadmixtures, inrequiredproportions. Themixture whenplacedinforms and allowed to cure, hardens into a rock-like mass known as concrete. The strength, durability and other characteristics of concrete depend upon the properties of itsingre- dients, on the proportions of mix, the method of compaction and other controls during placing, compaction and curing. All concrete requires curing in order that cement hy- dration can proceed so as to allow for development of strength, durability and other mechanicalcharacteristics.

\subsection{GlassFiber}

Revised Version Manuscript Received on 10, September 2019.

Jaison Joy Memadam, Research Scholar, Department of Civil Engineering, AcharyaNagarjuna University, Guntur, A.P, India(Email:

Dr. T.V.S Vara Lakshmi, Assistant professor, Head of Department of Civil Engineering, AcharyaNagarjunaUni- versity, Guntur, A.P, India. jaisonjoy88@gmail.com)

Fiberreinforcedconcreteisanewconstructionmaterialwhichi sdefinedascomposite material of cement mortar and the fibers. Addition of glass fiber into cement mortar eliminates the cracks and shrinkage in the surface. It also increases the tensile strength of concrete. Glass fibers can be incorporated into a matrix either in continuous or dis- continuous (chopped) lengths. Glass fibers have large tensile strength and elasticmod- ulus but have brittle stress- strain characteristics and low creep at room temperature. Glassfibersareusuallyroundandstraightwithdiametersranging from $0.005 \mathrm{~mm}$ to $0.015 \mathrm{~mm}$.

Glass fiber also called fiberglass. Fiberglass is a lightweight, extremely strong, and robust material. Although strength properties are some what lower than carbon fiber and it is less stiff, the material is typically far less brittle, and the raw materials are much less expensive. Its bulk strength and weight properties are also very favorable when compared to metals, and it can be easily formed using molding processes. Glass is the oldest, and most familiar, performance fiber. Fibers have been manufactured from glass since the1930s. Glass fiber is chemical inorganic fiber, obtained from molten glass of a specific composition. This glass is compound of quartz sand, limestone, kaolin, cal- cium fluoride (fluorspar), boric acid, natrium, sulphate, and clay. Glass fiber is made ofnaturalmaterials, sothatitsproductsareecologicallypureandn otharmfultohuman health. Glass fiber is highly light permeable and can be a semiconductor having excel- lent electronic, heat, and sound insulationcapacities.

\subsection{Calcium chloride( $\mathrm{CaCl}$ )}

Itisachemicaladmixtureandaby-productoftheSolvayproces sinthemanufacturing of sodium carbonate. Calcium chloride is available in two forms: (i) Regular flake calciumchlorideand(ii)concentratedflake,pellet,orgranularcalciu mchloride.Calcium chloride has been used in concrete since 1885 and finds application mainly in cold weather, when it allows the strength gain to approach that of concrete cured under nor- mal curing temperatures.

In normal conditions, calcium chloride is used to speed up the setting and hardening process for earlier finishing or mould turnaround. Aside from affecting setting time, calcium chloride has a minor effect on fresh concrete properties. It has been observed that addition of $\mathrm{CaCl} 2$ reduces bleeding. Initial and final setting times of concrete are significantly reduced by using calcium chloride. Historically, the use of calcium, par- ticularly in the form of calcium chloride, was thought to be an effective acceleration technique in concrete. In applications in which metal is not embedded in concrete, 


\section{STRENGTH CHARACTERISTICS OF GLASS FIBER REINFORCED CONCRETE (GFRC) USING CALCIUM CHLORIDE INTEGRAL CURING METHOD}

the use of calcium chloride as an accelerator is still permitted. Additional suggestions re- garding the use of calcium chloride as an accelerator include never using concentrations greater than $2 \%$ by cement weight as told by American Concrete Institute.

\section{MATERIALS AND METHODS}

\subsection{Cement}

Ordinary Portland cement was used for the experiments. The physical properties of the cement after the tests are given below.

Table 1. Physical properties of Cement

\begin{tabular}{|l|l|l|}
\hline S.No & Property & Value \\
\hline 1 & Grade & 53 \\
\hline 2 & Specific Gravity & 3.12 \\
\hline 3 & Fineness(cm2/gms) & 2100 \\
\hline 4 & Standard Consistency (\%) & 27 \\
\hline 5 & Initial Setting Time (min.) & 35 \\
\hline 6 & Final Setting Time (min.) & 420 \\
\hline
\end{tabular}

\subsection{Coarse and Fine aggregate}

Fine aggregate used for the study is having specific gravity 2.68. The sample is con- firming to zone II and fineness modulus is 3.18. Coarse Aggregate used is $10 \mathrm{~mm}$ and $20 \mathrm{~mm}$ crushed gravel of 2.71 specific gravity. Both coarse and fine aggregate was air- dried in the laboratory and sieve analysis was carried out. The fineness modulus was found out to be 7.13 for the coarse aggregate.

\subsection{Mix Proportions}

The investigation was aimed at studying the compressive strength of M30 grade Con- crete for different type of colored polythene paper curing. The mix proportions are cal- culated based on the IS 10262 and SP 23. The proportions of Cement: Sand: Coarse Aggregate: $w / c=(1: 1.87: 3.37: 0.45)$ was used for mixing.

\subsection{Calcium chloride}

Properties of calcium chloride $(\mathrm{CaCl} 2)$ -

- Appearance/Physical State - Powder

- Color - White

- Odor - Odorless or no characteristic odor

- Solubility description - Soluble in water

\subsection{Glass Fiber}

- Type : Alkali Resistant

- Specific gravity : 2.68

- Elastic Modulus : $72 \mathrm{GPa}$

- Tensile Strength : $2100 \mathrm{MPa}$

- Length : $12 \mathrm{~mm}$

- Density : $2680 \mathrm{Kg} / \mathrm{m} 3$

- Aspect Ratio : 857.1
- Color : White

- Filament Diameter : 14 micron

\subsection{Workability}

The internal surface of the cone mould used was thoroughly cleaned and applied with a light coat of oil. The mould was placed on a smooth, horizontal, rigid and nonabsor- bent surface. The mould was then filled in three layers with freshly mixed concrete, and each layer was tamped 25 times with tamping rod. After the top layer was rodded, the concrete was struck off the level with a trowel. The mould was removed from the con- crete immediately by raising it slowly in vertical direction. The difference in level be- tween the height of the mould and that of the highest point of the subsided concrete was measured using a meter rule. This difference in height in millimeter is recorded as the slump of the concrete

\subsection{Curing}

The curing were carried out for 28 days. During mixing of concrete, Calcium chloride is added to the mix as an accelerator. Then after dismantling from the mould, the specimen is kept in water for 28 days.

\subsection{Compressive strength and Tensile strength}

The compressive strength and tensile strength of the concrete is determined by using a Universal testing machine. Three cube $(150 * 150 * 150 \mathrm{~mm})$ specimens and three Cylindrical(150 mm diameter and $300 \mathrm{~mm}$ height) specimen were tested at 7,14 and 28 days of curing

\section{RESULTS AND DISCUSSION}

The following are the results obtained from the experiments.

Table 2. Workability of GFRC

\begin{tabular}{|l|l|l|}
\hline S.No & $\begin{array}{l}\text { Glass } \\
\text { Fiber }(\%)\end{array}$ & Slump(mm) \\
\hline 1 & 0 & 78 \\
\hline 2 & 0.5 & 74 \\
\hline 3 & 1 & 73 \\
\hline 4 & 1.5 & 71 \\
\hline 5 & 2 & 70 \\
\hline 6 & 2.5 & 68 \\
\hline 7 & 3 & 66 \\
\hline 8 & 3.5 & 64 \\
\hline 9 & 4 & 63 \\
\hline
\end{tabular}

Table 3. Workability of M30 concrete with calcium chloride integral curing

\begin{tabular}{|c|c|c|}
\hline S.No & $\begin{array}{l}\text { Calcium } \\
\text { chloride }(\%)\end{array}$ & $\operatorname{Slump}(\mathrm{mm})$ \\
\hline 1 & 0 & 78 \\
\hline 2 & 0.5 & 76 \\
\hline 3 & 1 & 74 \\
\hline 4 & 1.5 & 71 \\
\hline 5 & 2 & 69 \\
\hline 6 & 2.5 & 67 \\
\hline
\end{tabular}


Table 4. Compressive strength of GFRC after 7 days curing

\begin{tabular}{|c|c|c|c|c|c|}
\hline S.No & Glass Fiber(\%) & $\begin{array}{c}\text { Sample 1 } \\
(\mathbf{M P a})\end{array}$ & $\begin{array}{c}\text { Sample 2 } \\
(\mathbf{M P a})\end{array}$ & $\begin{array}{c}\text { Sample 3 } \\
(\mathbf{M P a})\end{array}$ & $\begin{array}{c}\text { Average } \\
(\mathbf{M P a})\end{array}$ \\
\hline 1 & 0 & 24.63 & 24.74 & 24.82 & 24.73 \\
\hline 2 & 0.5 & 25.40 & 25.92 & 25.04 & 25.42 \\
\hline 3 & 1 & 26.12 & 25.98 & 26.43 & 26.18 \\
\hline 4 & 1.5 & 26.28 & 23.13 & 26.84 & 26.42 \\
\hline 5 & 2 & 26.97 & 27.03 & 26.59 & 26.86 \\
\hline 6 & 2.5 & 27.22 & 27.27 & 27.44 & 27.31 \\
\hline 7 & 3 & 27.92 & 27.57 & 27.34 & 27.61 \\
\hline 8 & 3.5 & 27.14 & 26.98 & 27.34 & 27.15 \\
\hline 9 & 4 & 27.02 & 27.12 & 25.92 & 26.69 \\
\hline
\end{tabular}

Table 5. Compressive strength of GFRC after 14 days curing

\begin{tabular}{|l|l|l|l|l|l|}
\hline S.No & Glass Fiber(\%) & $\begin{array}{l}\text { Sample 1 } \\
(\mathbf{M P a})\end{array}$ & $\begin{array}{l}\text { Sample 2 } \\
\mathbf{( M P a})\end{array}$ & $\begin{array}{l}\text { Sample 3 } \\
(\mathbf{M P a})\end{array}$ & $\begin{array}{l}\text { Average } \\
(\mathbf{M P a})\end{array}$ \\
\hline 1 & 0 & 34.64 & 35.24 & 34.84 & 34.91 \\
\hline 2 & 0.5 & 35.17 & 34.92 & 35.73 & 35.27 \\
\hline 3 & 1 & 36.14 & 35.78 & 36.02 & 35.98 \\
\hline 4 & 1.5 & 36.22 & 36.12 & 36.33 & 36.22 \\
\hline 5 & 2 & 36.49 & 37.12 & 36.87 & 36.83 \\
\hline 6 & 2.5 & 36.88 & 37.45 & 36.75 & 37.03 \\
\hline 7 & 3 & 37.62 & 37.49 & 37.87 & 37.66 \\
\hline 8 & 3.5 & 37.13 & 36.82 & 36.91 & 36.95 \\
\hline 9 & 4 & 37.02 & 36.89 & 35.21 & 36.37 \\
\hline
\end{tabular}

Table 6. . Compressive strength of GFRC after 28 days curing

\begin{tabular}{|l|l|l|l|l|l|}
\hline S.No & Glass Fiber(\%) & $\begin{array}{l}\text { Sample 1 } \\
(\mathbf{M P a})\end{array}$ & $\begin{array}{l}\text { Sample 2 } \\
(\mathbf{M P a})\end{array}$ & $\begin{array}{l}\text { Sample 3 } \\
(\mathbf{M P a})\end{array}$ & $\begin{array}{l}\text { Average } \\
(\mathbf{M P a})\end{array}$ \\
\hline 1 & 0 & 38.68 & 39.54 & 38.12 & 38.78 \\
\hline 2 & 0.5 & 38.77 & 39.79 & 39.82 & 39.46 \\
\hline 3 & 1 & 38.89 & 39.98 & 40.12 & 39.66 \\
\hline 4 & 1.5 & 39.77 & 40.79 & 40.92 & 40.49 \\
\hline 5 & 2 & 40.91 & 41.23 & 41.37 & 41.17 \\
\hline 6 & 2.5 & 41.41 & 41.83 & 41.89 & 41.71 \\
\hline 7 & 3 & 42.13 & 41.97 & 42.49 & 42.26 \\
\hline 8 & 3.5 & 40.73 & 40.93 & 41.12 & 40.93 \\
\hline 9 & 4 & 40.13 & 39.45 & 39.98 & 39.85 \\
\hline
\end{tabular}

Table 7. Tensile strength of GFRC after 7 days curing

\begin{tabular}{|l|l|l|l|l|l|}
\hline S.No & Glass Fiber(\%) & $\begin{array}{l}\text { Sample 1 } \\
(\mathbf{M P a})\end{array}$ & $\begin{array}{l}\text { Sample 2 } \\
(\mathbf{M P a})\end{array}$ & $\begin{array}{l}\text { Sample 3 } \\
(\mathbf{M P a})\end{array}$ & $\begin{array}{l}\text { Average } \\
(\mathbf{M P a})\end{array}$ \\
\hline 1 & 0 & 3.43 & 3.49 & 3.32 & 3.41 \\
\hline 2 & 0.5 & 3.51 & 3.57 & 3.58 & 3.55 \\
\hline 3 & 1 & 3.63 & 3.71 & 3.79 & 3.71 \\
\hline 4 & 1.5 & 3.89 & 3.85 & 3.92 & 3.89 \\
\hline 5 & 2 & 3.94 & 3.97 & 4.11 & 4.01 \\
\hline 6 & 2.5 & 4.07 & 4.13 & 4.22 & 4.14 \\
\hline 7 & 3 & 4.27 & 4.31 & 4.29 & 4.29 \\
\hline 8 & 3.5 & 4.13 & 4.09 & 4.22 & 4.15 \\
\hline 9 & 4 & 4.11 & 4.05 & 4.01 & 4.06 \\
\hline
\end{tabular}



CHLORIDE INTEGRAL CURING METHOD

Table 8. Tensile strength of GFRC after 28 days curing

\begin{tabular}{|l|l|l|l|l|l|}
\hline S.No & Glass Fiber(\%) & $\begin{array}{l}\text { Sample 1 } \\
\text { (MPa) }\end{array}$ & $\begin{array}{l}\text { Sample 2 } \\
\text { (MPa) }\end{array}$ & $\begin{array}{l}\text { Sample 3 } \\
\text { (MPa) }\end{array}$ & $\begin{array}{l}\text { Average } \\
\text { (MPa) }\end{array}$ \\
\hline 1 & 0 & 5.38 & 5.12 & 5.47 & 5.32 \\
\hline 2 & 0.5 & 5.49 & 5.61 & 5.55 & 5.55 \\
\hline 3 & 1 & 5.69 & 5.77 & 5.81 & 5.76 \\
\hline 4 & 1.5 & 6.01 & 5.91 & 5.88 & 5.93 \\
\hline 5 & 2 & 6.17 & 6.31 & 6.21 & 6.23 \\
\hline 6 & 2.5 & 6.32 & 6.29 & 6.45 & 6.35 \\
\hline 7 & 3 & 6.49 & 6.46 & 6.59 & 6.51 \\
\hline 8 & 3.5 & 6.40 & 6.31 & 6.38 & 6.38 \\
\hline 9 & 4 & 6.31 & 6.37 & 6.29 & 6.32 \\
\hline
\end{tabular}

Table 9. Compressive strength of M30 concrete after 7 days curing

\begin{tabular}{|c|c|c|c|c|c|}
\hline S.No & Calcium Chloride(\%) & $\begin{array}{l}\text { Sample 1 } \\
(\mathbf{M P a})\end{array}$ & $\begin{array}{l}\text { Sample 2 } \\
\mathbf{( M P a )}\end{array}$ & $\begin{array}{l}\text { Sample 3 } \\
(\mathbf{M P a})\end{array}$ & $\begin{array}{l}\text { Average } \\
\text { (MPa) }\end{array}$ \\
\hline 1 & 0 & 24.63 & 24.74 & 24.82 & 24.73 \\
\hline 2 & 0.5 & 28.08 & 29.14 & 27.56 & 28.26 \\
\hline 3 & 1 & 27.82 & 29.11 & 29.85 & 28.92 \\
\hline 4 & 1.5 & 28.84 & 29.13 & 29.77 & 29.10 \\
\hline 5 & 2 & 29.47 & 30.83 & 30.17 & 30.16 \\
\hline 6 & 2.5 & 30.54 & 30.89 & 31.43 & 30.95 \\
\hline
\end{tabular}

Table 10. Compressive strength of M30 concrete after 14 days curing

\begin{tabular}{|c|c|l|l|l|l|}
\hline S.No & Calcium Chloride(\%) & $\begin{array}{l}\text { Sample 1 } \\
\text { (MPa) }\end{array}$ & $\begin{array}{l}\text { Sample 2 } \\
\text { (MPa) }\end{array}$ & $\begin{array}{l}\text { Sample 3 } \\
\text { (MPa) }\end{array}$ & $\begin{array}{l}\text { Average } \\
\text { (MPa) }\end{array}$ \\
\hline 1 & 0 & 34.64 & 35.24 & 34.84 & 34.91 \\
\hline 2 & 0.5 & 36.92 & 35.48 & 36.19 & 36.20 \\
\hline 3 & 1 & 35.94 & 36.77 & 37.41 & 36.71 \\
\hline 4 & 1.5 & 37.32 & 37.94 & 36.81 & 37.36 \\
\hline 5 & 2 & 38.12 & 38.77 & 38.41 & 38.43 \\
\hline 6 & 2.5 & 38.72 & 39.79 & 39.08 & 39.20 \\
\hline
\end{tabular}

Table 11. Compressive strength of M30 concrete after 28 days curing

\begin{tabular}{|c|c|c|c|c|c|}
\hline S.No & Calcium Chloride(\%) & $\begin{array}{l}\text { Sample 1 } \\
(\mathbf{M P a})\end{array}$ & $\begin{array}{l}\text { Sample 2 } \\
(\mathbf{M P a})\end{array}$ & $\begin{array}{l}\text { Sample 3 } \\
(\mathbf{M P a})\end{array}$ & $\begin{array}{l}\text { Average } \\
(\mathbf{M P a})\end{array}$ \\
\hline 1 & 0 & 38.68 & 39.54 & 38.12 & 38.78 \\
\hline 2 & 0.5 & 38.44 & 38.79 & 39.27 & 38.83 \\
\hline 3 & 1 & 38.97 & 39.74 & 39.91 & 39.54 \\
\hline 4 & 1.5 & 40.24 & 40.31 & 39.97 & 40.17 \\
\hline 5 & 2 & 40.79 & 40.88 & 41.37 & 41.01 \\
\hline 6 & 2.5 & 41.44 & 42.03 & 42.24 & 41.90 \\
\hline
\end{tabular}

Compressive Strength( $\mathrm{MPa}$ ) vs Curing days for different percentages of GFRC

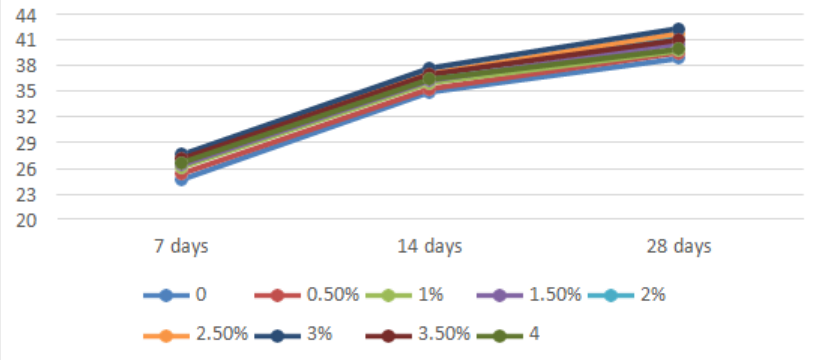

Compressive strength(MPa) vs Curing Daysfor different percentages of calcium chloride

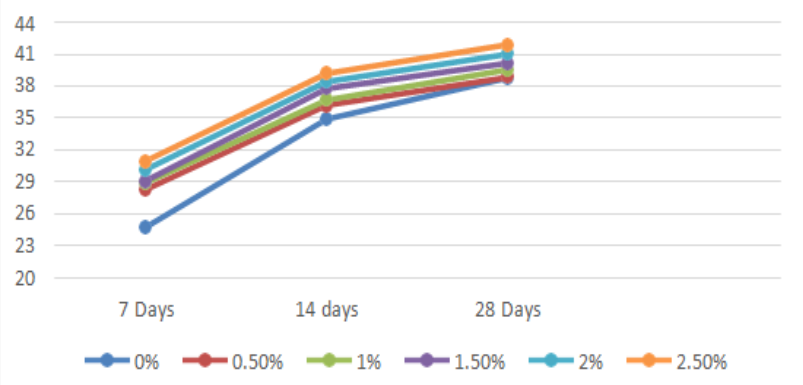




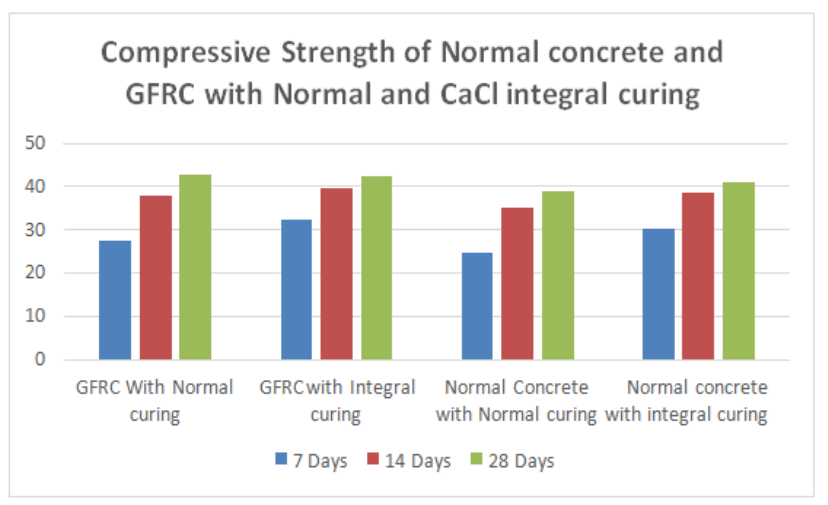

\section{CONCLUSIONS}

The following conclusions were made from the observations.

a) The optimum amount of glass fiber that can be added to M30 concrete is $3 \%$ and it leadsto

- $6.17 \%$ increase in the compressive strength ofconcrete

- $22.37 \%$ increase in the tensile strength ofconcrete

- $\quad$ Reduction in workability ( $78 \mathrm{~mm}$ to $66 \mathrm{~mm}$ )

b) The optimum amount of Calcium chloride that van be added to M30 concrete is $2 \%$ (ACI doesn't permits more than $2 \%$ as an accelerator) and it leadsto

- $22 \%$ increase in compressive strength at 7 days ofcuring

- $10 \%$ increase in compressive strength at 14 days ofcuring

- No much variation in compressive strength after 28 days ofcuring

- Reduction in workability (78 $\mathrm{mm}$ to $65 \mathrm{~mm}$ )

c) GFRC with $3 \%$ glass fiber under calcium chloride integral curing $(2 \%)$ leads

to

- $16 \%$ increase in compressive strength at 7 days ofcuring

- $4 \%$ increase in compressive strength at 14 days ofcuring

- $\quad$ No much variation in compressive strength after 28 days ofcuring

\section{REFERENCES}

1. Avci, H. Arikan, A. Akdemir, "Fracture behavior of glass fiber reinforced polymer compo- site", Cement and Concrete Research 34 (2004), pp.429-434.

2. Deshmukh S.H. Bhusari J. P, Zende A. M.Effect of Glass Fibres on Ordinary Portland ce- ments Concrete IOSR Journal of Engineering, June. 2012, Vol. 2(6) pp:1308-1312

3. Dhir, R.K. Hewlett, P.C. Dyer, T.D., Mechanisms of water retention in cement pastes con- taining a self-curing agent, $\|$ Magazine of Concrete Research, Vol No 50, Issue No 1, 1998, pp85-90.

4. J.D.Chaitanyakumar, G.V.S. Abhilash, P.Khasim Khan, G.Manikantasai,V.Taraka ram. - Assist Experimental Studies on Glass Fiber Concrete American Journal of Engineering Re- search (AJER) e-ISSN: 2320-0847 p-ISSN : 2320-0936 Volume-5, Issue-5,pp-100-104

5. Kavita S KeneandA.Mumtaj- Experimental Study on
Behavior of Steel and Glass Fiber Reinforced Concrete Composites Bonfring International Journal of Industrial Engineering and Management Science, Vol. 2, No. 4, December2012

6. Kumar Shantveerayya and VikasNikkamAn experimental study on the properties of glass fiber reinforced and ground granulated blast furnace slag concreteInternational Journal of Civil Engineering (SSRG-IJCE) - volume 3 Issue 3-March2016

7. Praveen Kumar Goud.E1, Praveen K.S optimization of percentages of steel and glass fiber reinforced concrete International Journal of Research in Engineering and Technology eISSN: 2319-1163 | p-ISSN:2321-7308.

8. S. S. Pimplikaran experimental study on glass fiber reinforced concrete International Re- search Journal of Engineering and Technology (IRJET) e-ISSN: 2395 -0056Volume: 03Is- sue: 04April-2016 